
\title{
28 Research Square \\ Synthesis of Ti3GeC2 Powders from Ti-Ge-TiC Mixtures by Pressureless Sintering
}

\section{Liu Qiaodan ( $\square$ liuqiaodan18@163.com )}

Southeast University

\section{Wubian Tian}

Southeast University

\section{Zhengming Sun}

Southeast University

\section{Peigen Zhang}

Southeast University

\section{Wenwen Zha}

Southeast University

\section{Shuo Sun}

Southeast University

\section{Research Article}

Keywords: Ti3GeC2, Pressureless sintering, Powders, Microstructure, Reaction path

Posted Date: November 13th, 2020

DOl: https://doi.org/10.21203/rs.3.rs-104533/v1

License: (c) (1) This work is licensed under a Creative Commons Attribution 4.0 International License. Read Full License 


\section{Abstract}

$\mathrm{Ti}_{3} \mathrm{GeC}_{2}$ compound has excellent electrical and mechanical properties, which can be used as a potential reinforcement for Ag-based electrical contact materials. However, few reports have been addressed on the synthesis of its powders. The present study, therefore, presents a new route to fabricate high-purity $\mathrm{Ti}_{3} \mathrm{GeC}_{2}$ powders from $\mathrm{Ti} / \mathrm{Ge} / \mathrm{TiC}$ by pressureless sintering in vacuum. The influence of sintering temperature and Ge content on the powder purity was studied and the optimized conditions are found to be $1550{ }^{\circ} \mathrm{C}$ and $\mathrm{Ti}: \mathrm{Ge}: \mathrm{TiC}=1: 1.1: 2$. In addition, the reaction path of $\mathrm{Ti} / \mathrm{Ge} / \mathrm{TiC}$ was revealed to be three steps: First, liquid Ge starts to react with Ti to form $\mathrm{Ti}_{5} \mathrm{Ge}_{3}$ compounds at around $1140{ }^{\circ} \mathrm{C}$; Then $\mathrm{Ti}_{5} \mathrm{Ge}_{3}$ consumes the liquid $\mathrm{Ge}$ and $\mathrm{TiC}$ to form $\mathrm{Ti}_{2} \mathrm{GeC}$ at around $1200{ }^{\circ} \mathrm{C}$; Finally, $\mathrm{Ti}_{2} \mathrm{GeC}$ transfers into $\mathrm{Ti}_{3} \mathrm{GeC}_{2}$ with the consumption of residual TiC. The present study lays the foundation for the subsequent applications of $\mathrm{Ti}_{3} \mathrm{GeC}_{2}$ powders in high performance composites.

\section{Introduction}

MAX phases, with the formula of $M_{n+1} A X_{n}$, where $n=1 \sim 3, M$ is an early transition metal, $A$ is an A-group (mostly IIIA and IV A) element, and $X$ is carbon or nitrogen, are a series of layered ternary carbides or nitrides[1,2]. They were first reported by Jeitschko and Nowotny in the early 1960s [3]and initially named in 2000 by Barsoum[4]. The unique crystal structure and combined bonding of MAX phases endow them with both metal and ceramic characteristics, such as excellent electrical and thermal conductivities, even exceeding the corresponding transition metal elements $[5,6]$. Accordingly, MAX phase materials have broad application prospects, including high-temperature structural materials, machinable ceramics, kiln furniture, wear and corrosion protection, heat exchangers, rotating parts etc $[4,7]$.

As a typical MAX phase, $\mathrm{Ti}_{3} \mathrm{GeC}_{2}$ has a theoretical density of $5.55 \mathrm{~g} / \mathrm{cm}^{3}$ and a hexagonal crystal structure[8, 9]. $\mathrm{Ti}_{3} \mathrm{GeC}_{2}$ exhibits moderate hardness (2 $6 \mathrm{GPa}$ ), high Young's modulus ( $\left.197 \mathrm{GPa}\right)$, excellent machinability, high yield strength, and significant plasticity at $1300{ }^{\circ} \mathrm{C}[7,10]$. It also shows excellent corrosion and oxidation resistance, remarkable thermal shock resistance, sound electrical and thermal conductivity $[10,11]$. Wolfsgruber et al. first fabricated bulk $\mathrm{Ti}_{3} \mathrm{GeC}_{2}[8]$ in 1967 by hot pressing at $1200{ }^{\circ} \mathrm{C}$ for $20 \mathrm{~h}$ from Ti, Ge, and C powder mixtures. In 1997, Barsoum et al.[7] synthesized $\mathrm{Ti}_{3} \mathrm{GeC}_{2}$ plates by hot pressing at $1500{ }^{\circ} \mathrm{C}$ for $4 \mathrm{~h}$. However, the phase purity was not satisfied due to the high content of carbide impurities, which was attributed to the severe loss of Ge during sintering. To compensate for the loss of $\mathrm{Ge}$, Kephart, et al. [12] added an excess of $\mathrm{Ge}$ in the starting materials during the preparation of $\mathrm{Ti}_{3} \mathrm{GeC}_{2}$ bulks by an arc melting ingot method, while several impurity phases like TiC, $\mathrm{Ti}_{5} \mathrm{Ge}_{3}$, and $\mathrm{Ti}_{2} \mathrm{GeC}$ were formed. To further improve the purity of $\mathrm{Ti}_{3} \mathrm{GeC}_{2}$, the same authors heated the reactants at $1200^{\circ} \mathrm{C}$ for about 100 hours[12], but a large amount of TiC, unreacted $\mathrm{Ge}$, and other Ti-Ge intermetallic compounds were still detected. Barsoum et al. [13] synthesized the bulk $\mathrm{Ti}_{3} \mathrm{GeC}_{2}$ and $\mathrm{Ti}_{3}\left(\mathrm{Si}_{\mathrm{x}} \mathrm{Ge}_{1-\mathrm{x}}\right) \mathrm{C}_{2}(\mathrm{x}=0.5,0.75)$ solid solutions by hot isostatic pressing (HIP) in 2004. However, these samples still contains a large amount of binary carbides unexpected. 
Since the first preparation of $\mathrm{Ti}_{3} \mathrm{GeC}_{2}$ in 1967, most studies focused on the synthesis of its bulk samples, but few reports concerned the direct production of $\mathrm{Ti}_{3} \mathrm{GeC}_{2}$ powders. Rahul et al. [14]synthesized $\mathrm{Ti}_{3} \mathrm{GeC}_{2}$ powder via pressureless sintering at $1500{ }^{\circ} \mathrm{C}$, containing $\mathrm{Ti}_{5} \mathrm{Ge}_{3}$ and $\mathrm{TiC}$ impurities. Generally, the $\mathrm{Ti}_{3} \mathrm{GeC}_{2}$ powders was fabricated from $\mathrm{Ti} / \mathrm{Ge} / \mathrm{C}$ raw materials[14], similar to the preparation of bulk samples $[7,8,12,13]$. The motivation to further improve $\mathrm{Ti}_{3} \mathrm{GeC}_{2}$ powder purity was inspired by the report that using $\mathrm{Ti} / \mathrm{Si} / \mathrm{TiC}$ instead of $\mathrm{Ti} / \mathrm{Si} / \mathrm{C}$ powder mixtures will significantly increase the phase purity of $\mathrm{Ti}_{3} \mathrm{SiC}_{2}$ [15]. The synthesis of high-purity MAX phase powders will benefit to the production of MAX components with complicated structures via ceramic processing like slip casting, and also the development of MAX-reinforced composites. For instance, MAX phase can be used as the reinforcements for metal-based electrical contacts[16-21], where the synthesis of high-purity MAX powder is the prerequisite for the developments of high-performance Ag-MAX composites.

In the present paper, therefore, $\mathrm{Ti}_{3} \mathrm{GeC}_{2}$ powders were prepared by pressureless sintering using $\mathrm{Ti}, \mathrm{Ge}$, and $\mathrm{TiC}$ as raw materials, and the processing parameters were optimized to improve the phase purity. Differential scanning calorimetry and X-ray diffraction analysis were applied to identify the formation mechanism.

\section{Experimental Procedures}

Powders of $\mathrm{Ti}(99.99 \%, \sim 45 \mu \mathrm{m}), \mathrm{Ge}(99.999 \%, \sim 75 \mu \mathrm{m})$, and $\mathrm{TiC}(99.95 \%, \sim 30 \mu \mathrm{m})$ were used as raw materials in this study. Ti/Ge/TiC powders with different molar ratios (1:0.9:2, 1:1:2, and 1:1.1:2) were mixed by Turbula mixer (T2F, Switzerland) for $24 \mathrm{~h}$. These homogeneous mixtures were then respectively placed in Tungsten crucible and sintered at $1500-1550^{\circ} \mathrm{C}$ at $10^{\circ} \mathrm{C} / \mathrm{min}$ for $2 \mathrm{~h}$ in a high-temperature vacuum furnace ( $10^{-4}$ bar). Based on the preliminary experiments, the processing parameters such as temperature and composition were optimized. To determine the reaction route,differential scanning calorimetry (DSC, Netzsch 404C, Germany) was conducted on a $1 \mathrm{Ti} / 1 \mathrm{Ge} / 2 \mathrm{TiC}$ powder mixture under the Ar atmosphere at a scanning rate of $10^{\circ} \mathrm{C} / \mathrm{min}$. The phase constituents of $\mathrm{Ti}_{3} \mathrm{GeC}_{2}$ powders were determined by X-ray diffraction (XRD, Bruker-AXS D8, Germany) with Cu Ka radiation at a scanning step of $0.05^{\circ}$ and scanning rate of $5 \% \mathrm{~min}$. Besides, The morphologies and chemical compositions of the synthesized $\mathrm{Ti}_{3} \mathrm{GeC}_{2}$ powders were characterized by a scanning electron microscope (SEM, FEI/Philips Sirion 2000, Netherlands) equipped with an energy dispersive spectrometer (EDS, Aztecs X-MAX 80).

\section{Results And Discussion}

\subsection{Effect of temperature on the formation of $\mathrm{Ti}_{3} \mathrm{GeC}_{2}$}

To eliminate these impurity phases, the sintering temperature of $\mathrm{Ti}_{3} \mathrm{GeC}_{2}$ powders was examined from $1500{ }^{\circ} \mathrm{C}$ to $1550^{\circ} \mathrm{C}$. Figure 1 a shows the XRD results of $1 \mathrm{Ti} / 1 \mathrm{Ge} / 2 \mathrm{TiC}$ powder sintered in vacuum for $2 \mathrm{~h}$ at different temperatures. At $1500{ }^{\circ} \mathrm{C}$, the main phase of $\mathrm{Ti}_{3} \mathrm{GeC}_{2}$ has been formed, but significant amount of $\mathrm{TiC}$ remains in the product, which is attributed to the relatively low reaction temperature and 
thus the residual TiC unreacted. With the increase of temperature to $1550{ }^{\circ} \mathrm{C}$, the content of $\mathrm{Ti}_{3} \mathrm{GeC}_{2}$ in the product continues to increase, and the content of $\mathrm{TiC}$ decreases significantly if compared with 1500 ${ }^{\circ} \mathrm{C}$. Therefore, the $\mathrm{Ti}_{3} \mathrm{GeC}_{2}$ sintered from $1 \mathrm{Ti} / 1 \mathrm{Ge} / 2 \mathrm{TiC}$ powder mixture at $1550{ }^{\circ} \mathrm{C}$ has relatively high phase purity.

For comparison, Fig. $1 \mathrm{~b}$ presents the XRD results of $3 \mathrm{Ti} / 1 \mathrm{Ge} / 2 \mathrm{C}$ powder mixtures sintered in vacuum for $2 \mathrm{~h}$ at $1500{ }^{\circ} \mathrm{C}$ and $1550^{\circ} \mathrm{C}$. Accordingly, the large amount of residual $\mathrm{TiC}$ at $1500^{\circ} \mathrm{C}$ and the gradually increased phase purity of $\mathrm{Ti}_{3} \mathrm{GeC}_{2}$ at $1550{ }^{\circ} \mathrm{C}$ in the product sintered from $3 \mathrm{Ti} / 1 \mathrm{Ge} / 2 \mathrm{C}$ powder mixtures can be derived. Thses results is consitent with the literature. However, if compared with $1 \mathrm{Ti} / 1 \mathrm{Ge} / 2 \mathrm{TiC}$ specimens, the $3 \mathrm{Ti} / 1 \mathrm{Ge} / 2 \mathrm{C}$ ones produces higher $\mathrm{TiC}$ content in final products at the same sintering temperature according to the stronger peak intensity of $\mathrm{TiC}$ at $41.7^{\circ}$, which means the relativly lower phase purity. Therefore, $\mathrm{Ti} / \mathrm{Ge} / \mathrm{TiC}$ powder mixtures were utilized as starting materials to synthesize $\mathrm{Ti}_{3} \mathrm{GeC}_{2}$ powder in the following experiments.

\subsection{Effect of Ge molar ratio on the formation of $\mathrm{Ti}_{3} \mathrm{GeC}_{2}$}

In addition to sintering temperature, the composition of raw materials also affects the phase purity of $\mathrm{Ti}_{3} \mathrm{GeC}_{2}$ powder. $1 \mathrm{Ti} / \mathrm{xGe} / 2 \mathrm{TiC}$ powder mixtures with different $\mathrm{Ge}$ contents were sintered at $1550{ }^{\circ} \mathrm{C}$ for $2 \mathrm{~h}$ to fabricate $\mathrm{Ti}_{3} \mathrm{GeC}_{2}$ powders. They were labled as S1 (1Ti/0.9Ge/2TiC), S2 (1Ti/1.0Ge/2TiC) and S3 $(1 \mathrm{Ti} / 1.1 \mathrm{Ge} / 2 \mathrm{TiC})$, respectively.

As shown in Fig. 2, the $\mathrm{S} 1$ sample consists of the main phase $\mathrm{Ti}_{3} \mathrm{GeC}_{2}$, with a small amount of $\mathrm{TiC}$ and $\mathrm{Ti}_{2} \mathrm{GeC}$ detected. When the content of $\mathrm{Ge}$ increases to 1.0 in the $\mathrm{S} 2$ sample, the amount of $\mathrm{Ti}_{3} \mathrm{GeC}_{2}$ increases and those of $\mathrm{TiC}$ and $\mathrm{Ti}_{2} \mathrm{GeC}$ decreases accordingly. With the further increase of Ge content to 1.1 in $\mathrm{S} 3$ sample, $\mathrm{Ti}_{3} \mathrm{GeC}_{2}$ dominates the phase constituents with trace $\mathrm{Ti}_{2} \mathrm{GeC}$ and $\mathrm{TiC}$.

The Ge element exists as a liquid phase and promotes the formation of $\mathrm{Ti}_{3} \mathrm{GeC}_{2}$ phase during the sintering process. When the content of $\mathrm{Ge}$ is less than the stoichiometric value of 1.0 , the liquid Ge phase may become insufficient due to the evaporation loss at high temperatures during the sintering of $\mathrm{Ti} / \mathrm{Ge} / \mathrm{TiC}$ mixtures. Therefore, raw materials like TiC is left in the final product. Meanwhile, a small amount of $\mathrm{Ti}_{2} \mathrm{GeC}$ as intermediate phase is remained, as shown in $\mathrm{S} 1$ and $\mathrm{S} 2$ samples. When the content of Ge element reaches 1.1, the excessive Ge compensates its loss, accompanying with the mostly consumed $\mathrm{TiC}$ and the promoted transformation from $\mathrm{Ti}_{2} \mathrm{GeC}$ to $\mathrm{Ti}_{3} \mathrm{GeC}_{2}$, as shown in $\mathrm{S} 3$ sample.

Figures 3(a)-(c) presents the respective morphologies of the synthesized powders of S1, S2, and S3 samples, all of which have the typically layered structures of MAX phases. EDS patterns suggest the presence of $\mathrm{Ti}, \mathrm{Ge}$ and $\mathrm{C}$ elements and the $\mathrm{Ti} / \mathrm{Ge}$ ratios change slightly from 3.18-3.28, indicating the high purity of $\mathrm{Ti}_{3} \mathrm{GeC}_{2}$ powders. The content of $\mathrm{Ge}$ in raw materials seems hardly to affect the microstructure of $\mathrm{Ti}_{3} \mathrm{GeC}_{2}$ powders. Therefore, the synthesized conditions of $\mathrm{Ti}_{3} \mathrm{GeC}_{2}$ powders are optimized to be the starting materials of $1 \mathrm{Ti} / 1.1 \mathrm{Ge} / 2 \mathrm{TiC}$ sintered at $1550^{\circ} \mathrm{C}$ for $2 \mathrm{~h}$. 


\subsection{Powder Synthesis}

Figure 4 displays the DSC curve of $1 \mathrm{Ti} / 1 \mathrm{Ge} / 2 \mathrm{TiC}$ powder mixture heated from room temperature to $1350^{\circ} \mathrm{C}$ at a rate of $10^{\circ} \mathrm{C} / \mathrm{min}$. There is a sharp endothermic peak near $942^{\circ} \mathrm{C}$, which corresponds to the melting of $\mathrm{Ge}$. The formation of liquid Ge benefits to the diffusion and reaction among the raw materials. The broad exothermic peak appears at $1140-1200^{\circ} \mathrm{C}$, suggesting some chemical reactions take place within this temperature range.

To determine the chemical reactions and phase changes of the raw materials during the heating process, $1 \mathrm{Ti} / 1 \mathrm{Ge} / 2 \mathrm{TiC}$ powders were respectively sintered at $1140^{\circ} \mathrm{C}, 1200^{\circ} \mathrm{C}$ and $1250^{\circ} \mathrm{C}$ for $2 \mathrm{~h}$, which corresponds to the starting, the ending and a higher temperatures to the exothermic peak. Figure 5 shows the XRD patterns of three samples sintered at these temperatures.

As sintered at $1140{ }^{\circ} \mathrm{C}$, the sample is composed of a large amount of $\mathrm{Ti}_{5} \mathrm{Ge}_{3}$ with a significant amount of $\mathrm{Ge}$ and $\mathrm{TiC}$ raw materials, as well as a small amount of $\mathrm{Ti}_{2} \mathrm{GeC}$. This indicates that the reaction between $\mathrm{Ti}$ and liquid $\mathrm{Ge}$ to form $\mathrm{Ti}_{5} \mathrm{Ge}_{3}$ contributes mainly the appearance of exothermic peak at the starting temperature. For the sample sintered at $1200{ }^{\circ} \mathrm{C}$, most of the peaks can be indexed to $\mathrm{Ti}_{2} \mathrm{GeC}$ phase with a small amount of $\mathrm{TiC}$ and a trace of $\mathrm{Ti}_{5} \mathrm{Ge}_{3}$ and residual $\mathrm{Ge}$. With the increase of sintering temperature, $\mathrm{Ti}_{5} \mathrm{Ge}_{3}$ reacts with $\mathrm{Ge}$ and $\mathrm{TiC}$ to form $\mathrm{Ti}_{2} \mathrm{GeC}$, which explains the exothermic peak around the ending temperature. Note that these results provide a ready method to fabricate high-purity $\mathrm{Ti}_{2} \mathrm{GeC}$ powders. At temperatures higher than the exothermic peak, $\mathrm{Ti}_{3} \mathrm{GeC}_{2}$ phase appears with the decreasing amount of $\mathrm{Ti}_{2} \mathrm{GeC}$ and $\mathrm{TiC}$, indicating the formation of $\mathrm{Ti}_{3} \mathrm{GeC}_{2}$ with the consumption of $\mathrm{Ti}_{2} \mathrm{GeC}$ and $\mathrm{TiC}$. Therefore, the reaction route of $\mathrm{Ti}_{3} \mathrm{GeC}_{2}$ from $\mathrm{Ti} / \mathrm{Ge} / \mathrm{TiC}$ powder mixtures can be described as follows:
At $942^{\circ} \mathrm{C}$
$\mathrm{Ge}(\mathrm{s}) \rightarrow \mathrm{Ge}(1)$
At $\sim 1140^{\circ} \mathrm{C}$
$5 \mathrm{Ti}+3 \mathrm{Ge}(1) \rightarrow \mathrm{Ti}_{5} \mathrm{Ge}_{3}$
At $1140^{\circ} \mathrm{C} \sim 1200^{\circ} \mathrm{C}$
$\mathrm{Ti}_{5} \mathrm{Ge}_{3}+2 \mathrm{Ge}+5 \mathrm{TiC} \rightarrow 5 \mathrm{Ti}_{2} \mathrm{GeC}$
At $1200^{\circ} \mathrm{C} \sim 1550^{\circ} \mathrm{C}$
$\mathrm{Ti}_{2} \mathrm{GeC}+\mathrm{TiC} \rightarrow \mathrm{Ti}_{3} \mathrm{GeC}_{2}$

\section{Conclusions}

The present study provides a new route to fabricate high-purity $\mathrm{Ti}_{3} \mathrm{GeC}_{2}$ powders from $\mathrm{Ti} / \mathrm{Ge} / \mathrm{TiC}$ by pressureless sintering in vacuum. The influence of sintering temperature and $\mathrm{Ge}$ content on the $\mathrm{Ti}_{3} \mathrm{GeC}_{2}$ powder purity and the corresponding reaction route was investigated. The main conclusions are as follows: 
1. High-purity $\mathrm{Ti}_{3} \mathrm{GeC}_{2}$ powders were successfully synthesized by pressureless sintering from the starting powder mixture of $1 \mathrm{Ti} / 1.1 \mathrm{Ge} / 2 \mathrm{TiC}$ at $1550{ }^{\circ} \mathrm{C}$ for $2 \mathrm{~h}$. The purity of $\mathrm{Ti}_{3} \mathrm{GeC}_{2}$ samples is mainly related to the sintering temperature and the Ge content in starting composition.

2. The reaction route of $\mathrm{Ti} / \mathrm{Ge} / \mathrm{TiC}$ power mixtures to $\mathrm{Ti}_{3} \mathrm{GeC}_{2}$ was revealed to be three steps: First, $\mathrm{Ge}$ melts at $942{ }^{\circ} \mathrm{C}$ and starts to react with $\mathrm{Ti}$ to form $\mathrm{Ti}_{5} \mathrm{Ge}_{3}$ at $1140{ }^{\circ} \mathrm{C}$; Then, $\mathrm{Ti}_{2} \mathrm{GeC}$ phase is completely formed by consuming $\mathrm{Ti}_{5} \mathrm{Ge}_{3}$, Ge and $\mathrm{TiC}$ at $1200{ }^{\circ} \mathrm{C}$; finally, $\mathrm{Ti}_{2} \mathrm{GeC}$ reacts with residual $\mathrm{TiC}$ to form $\mathrm{Ti}_{3} \mathrm{GeC}_{2}$ gradually at higher temperatures.

\section{Declarations}

\section{Acknowledgments}

The authors wish to acknowledge the financial support of National Natural Science Foundation (Nos. 51731004 and 51671054), the Natural Science Foundation of Jiangsu Province (BK20181285).

\section{References}

1. Barsoum MW. Mechanical Properties of the MAX Phases. Encyclopedia of Materials: Science and Technology 2004: 1-16

2. Sun ZM (2011) Progress in research and development on MAX phases: a family of layered ternary compounds. Int Mater Rev 56:143-166

3. Jeitschko W, Nowotny H, Benesovsky F (1964) Carbides of formula $T_{2} M C$. Journal of The LessCommon Metals 7:133-138

4. Barsoum MW (2000) The $M_{N+1} A X_{N}$ phases: A new class of solids. Prog Solid State Chem 28:201281

5. Finkel P, Barsoum MW, Hettinger JD et al. Low-temperature transport properties of nanolaminates $\mathrm{Ti}_{3} \mathrm{AlC}_{2}$ and $\mathrm{Ti}_{4} \mathrm{AlN}_{3}$. Physical Review B 2003, 67: 235108.1-235108.6

6. Lofland S, Hettinger J, Meehan T et al (2006) Electron-phonon coupling in $M_{n+1} A X_{n}$-phase carbides. Phys Rev B 74:3840-3845

7. Michel B (1997) Dmitri, et al. Layered machinable ceramics for high temperature applications. Scripta Mater 36:535-541

8. Wolfsgruber $\mathrm{H}$, Nowotny $\mathrm{H}$, Benesovsky $\mathrm{F}$ et al (1967) Die Kristallstruktur von $\mathrm{Ti}_{3} \mathrm{GeC}_{2}$. Monatshefte Für Chemie Verwandte Tle Anderer Wissenschaften 98:2403-2405

9. Magnuson M, Palmquist JP, Mattesini $\mathrm{M}$ et al (2005) Electronic structure investigation of $\mathrm{Ti}_{3} \mathrm{AlC}_{2}$, $\mathrm{Ti}_{3} \mathrm{SiC}_{2}$, and $\mathrm{Ti}_{3} \mathrm{GeC}_{2}$ by soft-X-ray emission spectroscopy. Phys Rev B 72:245101

10. Radovic M, Barsoum MW, Ganguly A et al (2006) On the elastic properties and mechanical damping of $\mathrm{Ti}_{3} \mathrm{SiC}_{2}, \mathrm{Ti}_{3} \mathrm{GeC}_{2}, \mathrm{Ti}_{3} \mathrm{Si}_{0.5} \mathrm{Al}_{0.5} \mathrm{C}_{2}$ and $\mathrm{Ti}_{2} \mathrm{AlC}$ in the 300-1573 $\mathrm{K}$ temperature range. Acta Mater 54:2757-2767 
11. Mane RB, Ampolu H, Rohila $\mathrm{S}$ et al (2019) Oxidation kinetics of $\mathrm{Ti}_{3} \mathrm{GeC}_{2} \mathrm{MAX}$ phase. Corros Sci $151: 81-86$

12. Kephart JS, Carim AH (1998) Ternary Compounds and Phase Equilibria in Ti-Ge-C and Ti-Ge-B. Cheminform 29:3253-3258

13. Ganguly Z, Barsoum MW (2004) Synthesis and mechanical properties of $\mathrm{Ti}_{3} \mathrm{GeC}_{2}$ and $\mathrm{Ti}_{3}\left(\mathrm{Si}_{x} \mathrm{Ge}_{1-}\right.$ x) $\mathrm{C}_{2}(\mathrm{x}=0.5,0.75)$ solid solutions. Journal of Alloys Compounds 376:287-295

14. Mane RB, Haribabu A, Panigrahi BB (2017) Synthesis and Sintering of $\mathrm{Ti}_{3} \mathrm{GeC}_{2} \mathrm{MAX}$ Phase Powders. Ceram Int 44:890-893

15. Yang S, Sun ZM, Hashimoto H (2003) Synthesis of Single-Phase $\mathrm{Ti}_{3} \mathrm{SiC}_{2}$ Powder. J Eur Ceram Soc 23:3147-3152

16. Zhang $\mathrm{Y}$, Sun $\mathrm{ZM}$, Zhou Y (1999) $\mathrm{Cu} / \mathrm{Ti}_{3} \mathrm{SiC}_{2}$ composite: a new electrofriction material. Material Research Innovations 3:80-84

17. Dudina DV, Mali VI, Anisimov AG et al (2013) $\mathrm{Ti}_{3} \mathrm{SiC}_{2}$-Cu composites by mechanical milling and spark plasma sintering: Possible microstructure formation scenarios. Met Mater Int 19:1235-1241

18. Ding JX, Tian WB, Sun ZM (2018) Arc erosion behavior of $A g / T i_{3} A l C_{2}$ electrical contact materials. J Alloy Compd 740:669-676

19. Ding JX, Tian WB, Zhang PG et al (2019) Preparation and arc erosion properties of $\mathrm{Ag} / \mathrm{Ti}_{2} \mathrm{SnC}$ composites under electric arc discharging. Journal of Advanced Ceramics 8:90-101

20. Ding JX, Tian WB, Wang DD, et al. Microstructure evolution, oxidation behavior and corrosion mechanism of $\mathrm{Ag} / \mathrm{Ti}_{2} \mathrm{SnC}$ composite during dynamic electric arc discharging. Journal of Alloys \& Compounds 2019, 785: 1086-1096.

21. Zhang M, Tian WB, Zhang PG et al (2018) Microstructure and properties of Ag- $\mathrm{Ti}_{3} \mathrm{SiC}_{2}$ contact materials prepared by pressureless sintering. International Journal of Minerals Metallurgy Materials 25:810-816

\section{Figures}



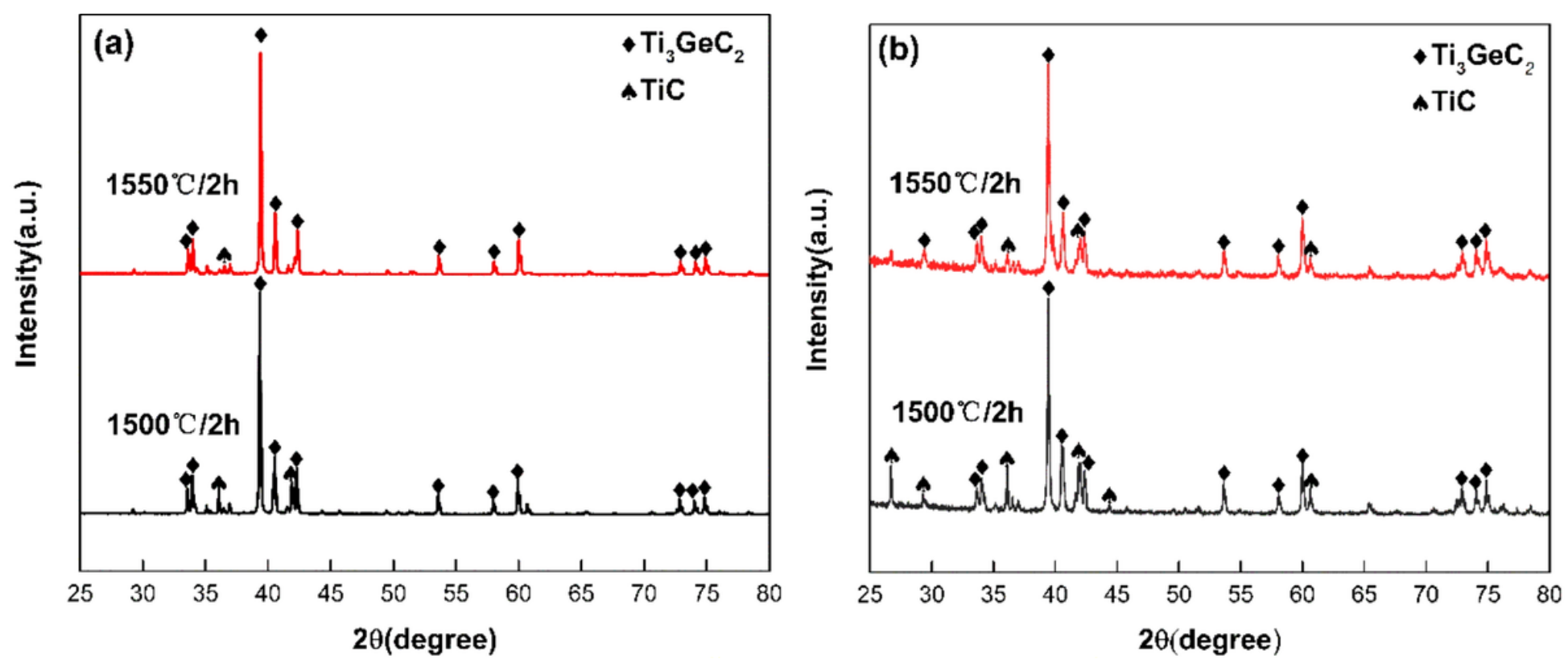

Figure 1

XRD patterns of (a) $1 \mathrm{Ti} / 1 \mathrm{Ge} / 2 \mathrm{TiC}$ and (b) $3 \mathrm{Ti} / 1 \mathrm{Ge} / 2 \mathrm{C}$ powder mixtures sintered at different temperatures for $2 h$. 


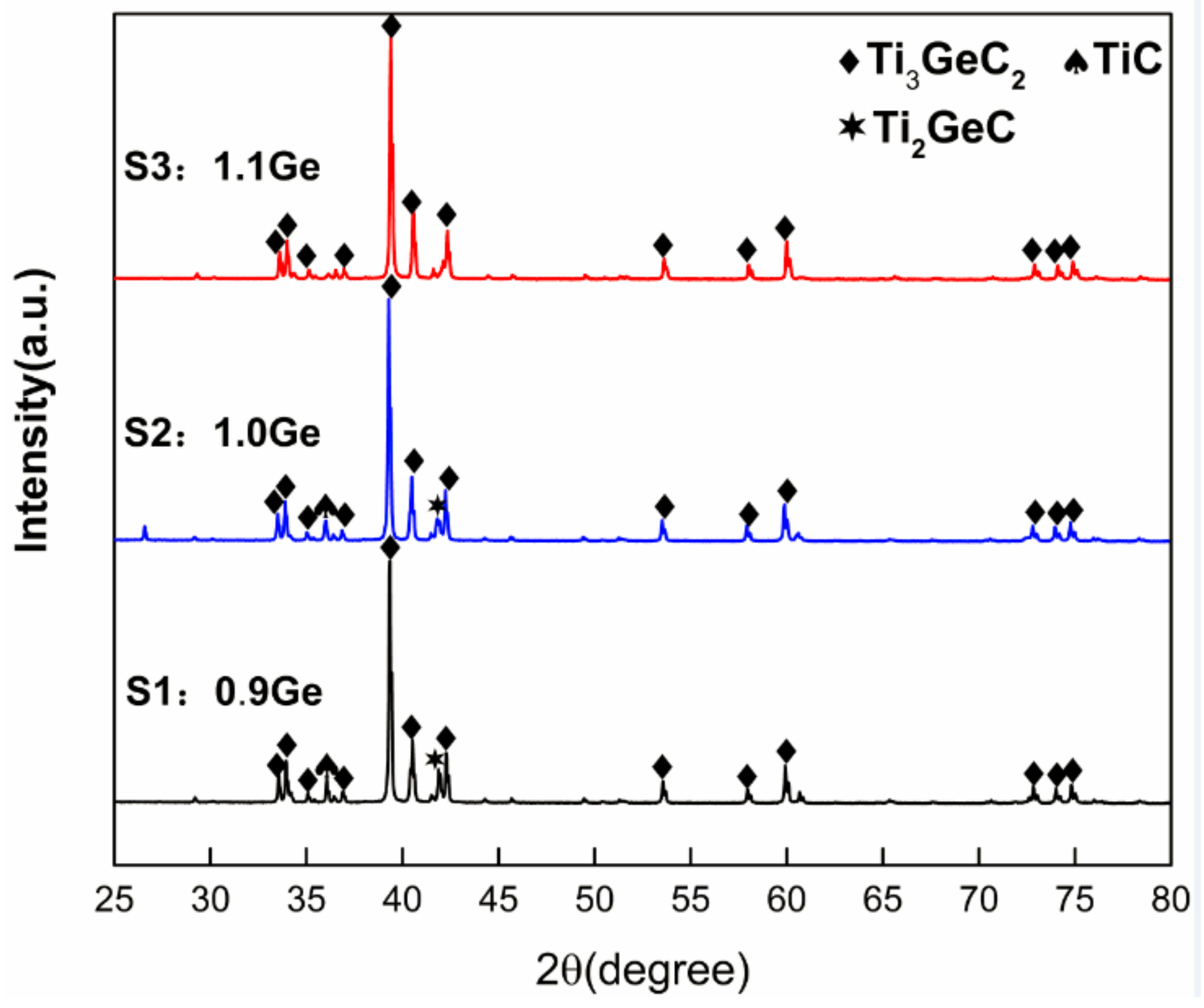

Figure 2

XRD patterns of $1 \mathrm{Ti} / \mathrm{xGe} / 2 \mathrm{TiC}$ powder mixtures with different $\mathrm{Ge}$ contents sintered at $1550{ }^{\circ} \mathrm{C}$ for $2 \mathrm{~h}$ 

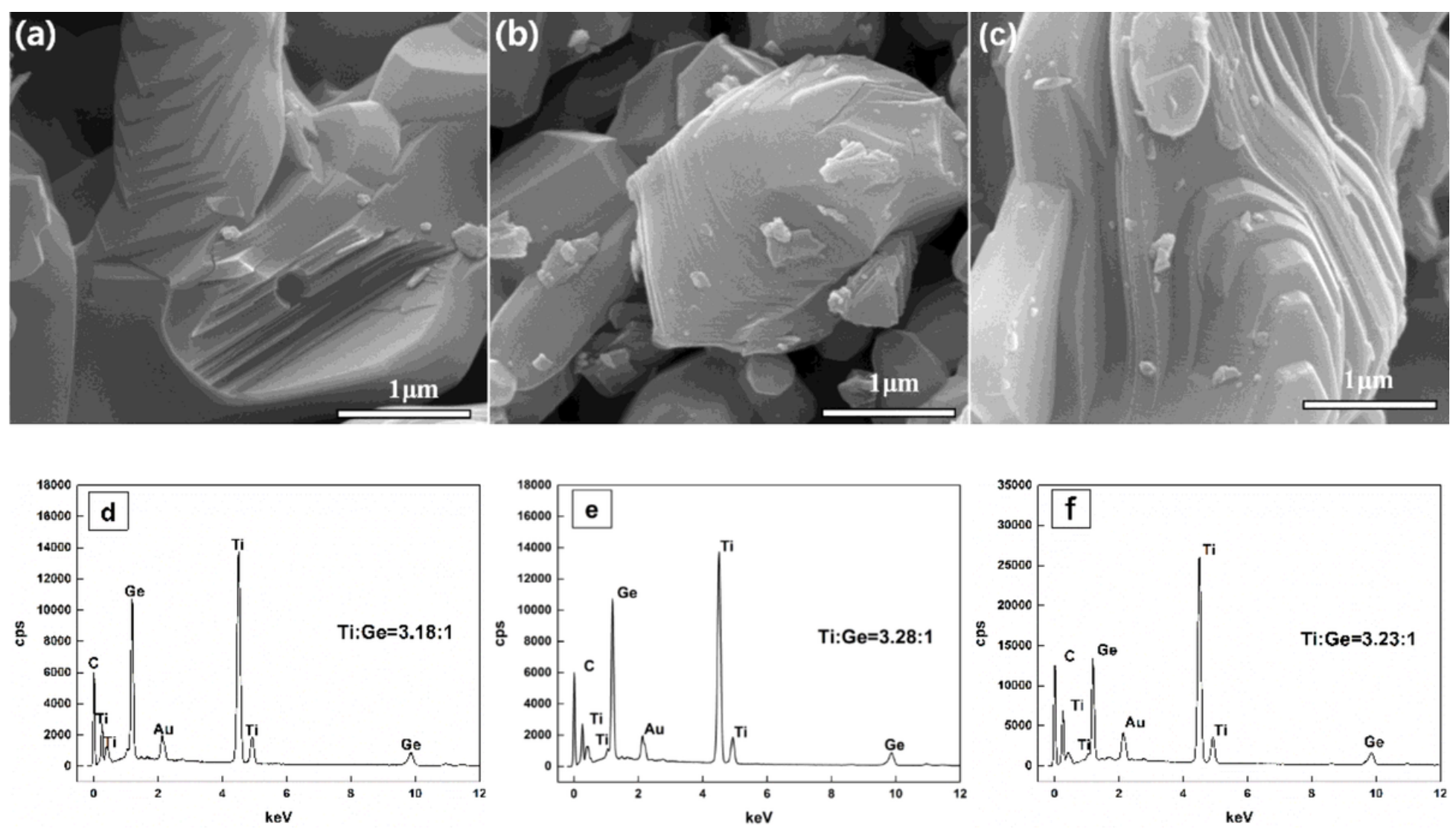

\section{Figure 3}

Typical morphologies of Ti3GeC2 in the synthesized powders. (a) sample S1;(b) sample S2; (c) sample S3 


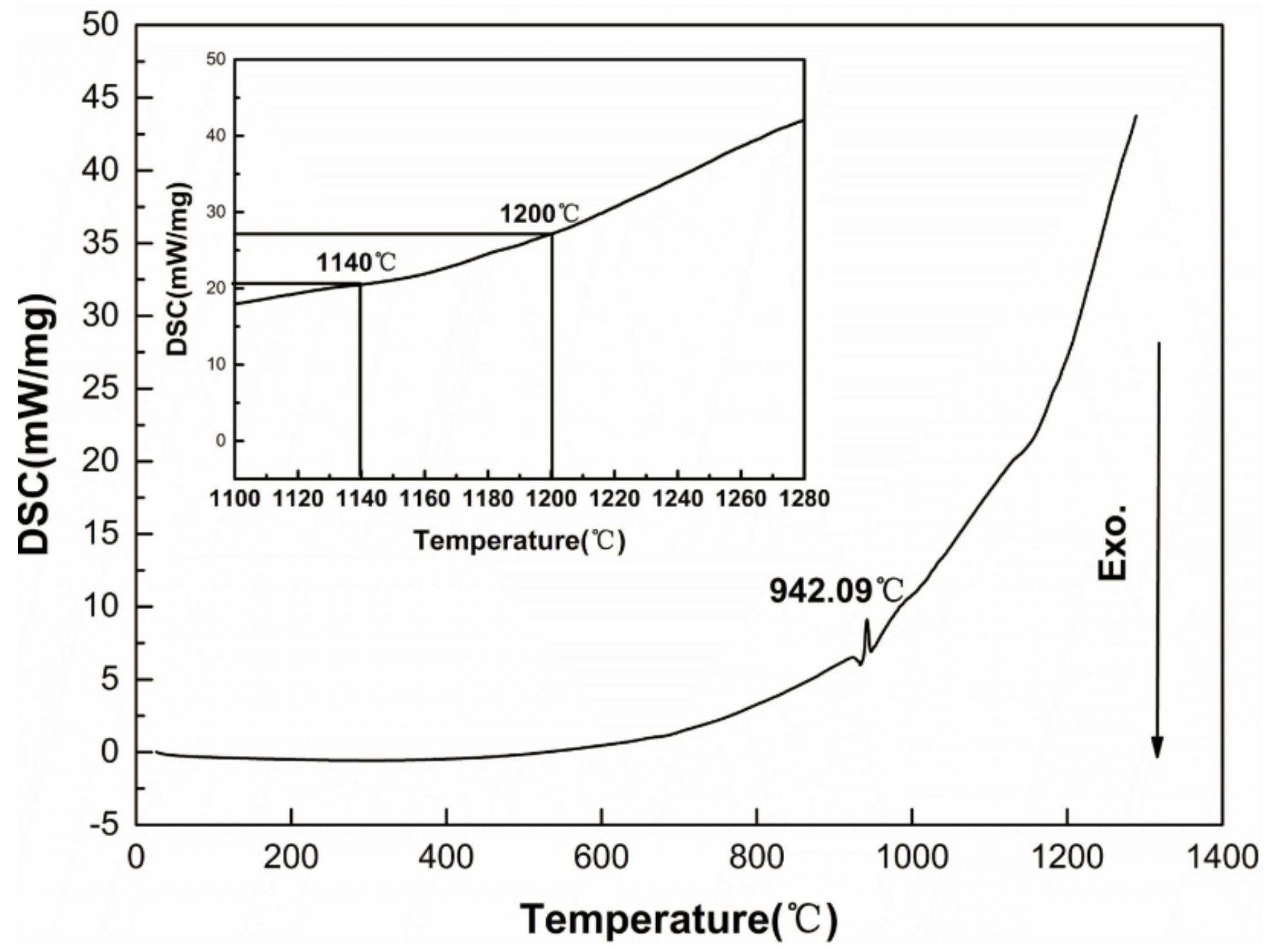

Figure 4

DSC curve of $1 \mathrm{Ti} / 1.1 \mathrm{Ge} / 2 \mathrm{TiC}$ powder heated to $1350^{\circ} \mathrm{C}$ at $10^{\circ} \mathrm{C} / \mathrm{min}$. 


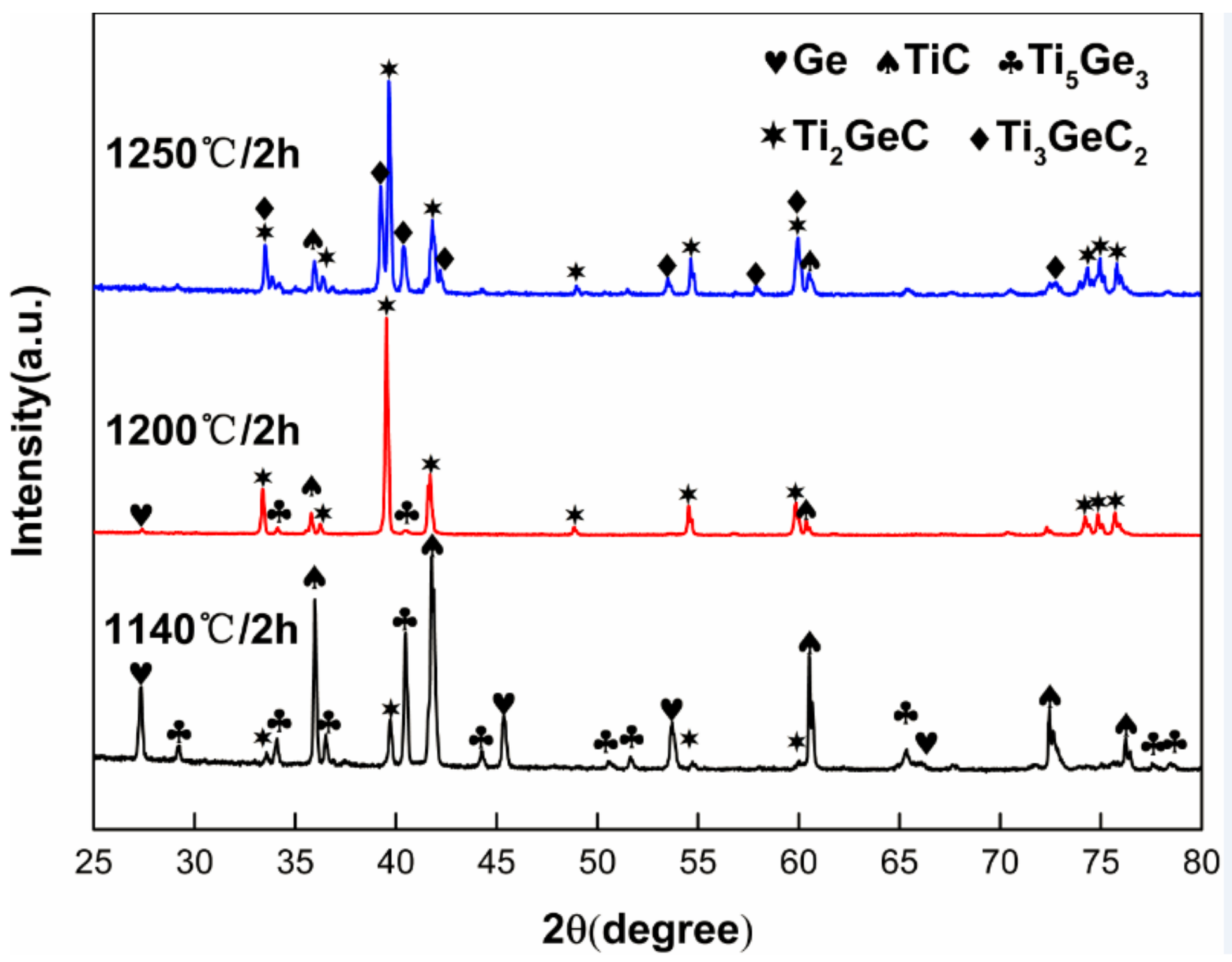

Figure 5

XRD patterns of $1 \mathrm{Ti} / 1 \mathrm{Ge} / 2 \mathrm{TiC}$ powder mixtures sintered from $1140{ }^{\circ} \mathrm{C}$ to $1250^{\circ} \mathrm{C}$. 